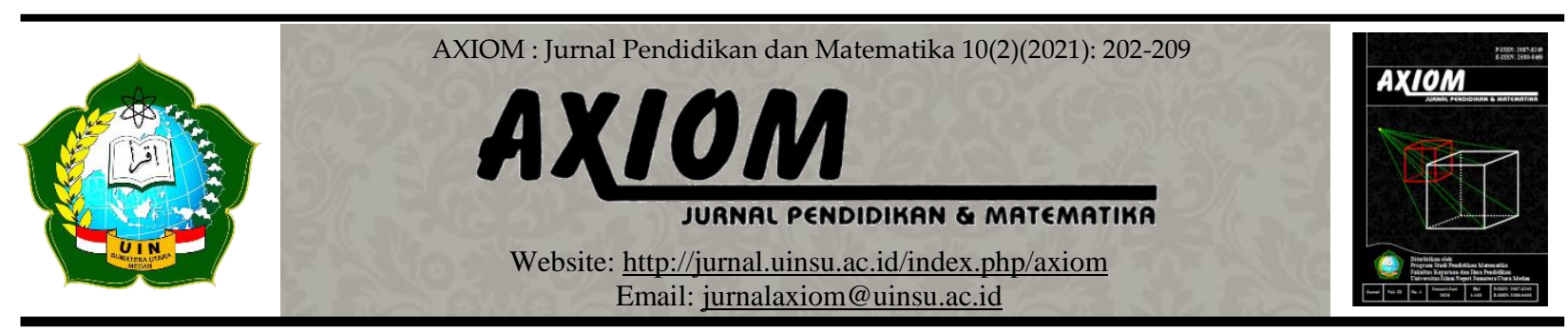

\title{
MATEMATIKA DALAM FILSAFAT PENDIDIKAN
}

\author{
Oleh: \\ Dwi Novita Sari ${ }^{1}$, Dian Armanto ${ }^{2}$ \\ ${ }^{1,2}$ Pendidikan Matematika, Program Doktor, Universitas Negeri Medan \\ E-mail: ${ }^{\text {dwinovita@ umnaw.ac.id }}$
}

doi : 10.30821/axiom.v10i2.10302

\begin{abstract}
Abstrak:
Tujuan artikel ini adalah memberikan informasi mengenai pengertian filsafat matematika, pengertian filsafat pendidikan dan hubungan antara matematika dengan filsafat pendidikan. Jenis penelitian yang digunakan adalah penelitian deskriptif dan studi literatur (library research). Temuan dalam artikel ini adalah hubungan antara matematika dan filsafat pendidikan yang saling bersinergi satu sama lain. Kesamaan antara matematika dan filsafat adalah memiliki objek kajian yang sama yaitu begerak pada tingkat generalitas dan abstraksi yang tinggi, mempergunakan akal/ rasional dan tidak melakukan eksperimen, serta tidak memerlukan peralatan laboratorium. Namun, matematika dan filsafat juga memiliki perbedaan yaitu jenis metode dalam menelaah suatu kebenaran. Matematika menggunakan metode deduksi dimana kebenaran dari hasil penelaahannya harus dapat ditunjukan dengan serangkaian langkah pembuktian. Sedangkan filsafat menggunakan macam-macam metode rasional dimana proses pembuktian itu tidak harus terjadi tetapi harus berlangsung dengan alasan-alasan yang diperoleh dari penalaran serta dapat bersifat fleksibel.
\end{abstract}

Kata Kunci:

Matematika, Filsafat, Pendidikan

\section{Abstract:}

This study aims to inform the concept of philosophy in mathematics, the concept of philosophy in education, and the relationship between mathematics and the philosophy of education. This study follows a descriptive approach with a literature study (library research). The findings indicate the relationship between mathematics and educational philosophy that synergize with each other. The similarity between mathematics and philosophy is that they have the same object of study, namely dealing with a high level of generality and abstraction, using reason/rationality, not conducting experiments, not requiring laboratory equipment. However, mathematics and philosophy are also different in terms of the method in examining a truth. Mathematics uses deduction where the truth of the results of the study must be presented by steps of proving evidence. Meanwhile, philosophy uses various traditional methods where the process of proving evidence does not need to be presented, but it must take place with reasons derived from reasoning and can be flexible.

\section{Keywords:}

Mathematics, Philosophy, Education 


\section{A. Pendahuluan}

Filsafat dikatakan sebagai ilmu karena filsafat mengandung empat pernyataan ilmiah yaitu bagaimana, mengapa, kemana dan apa (Ginting \& Situmorang, 2008; Anwar, 2015; Susanto, 2021). Pertanyaan bagaimana mengandung sifat yang dapat ditangkap atau tampak oleh indra, jawaban yang didapat bersifat deskriptif. Pertanyaan mengapa mengandung sebab (asal mula) suatu objek, jawaban yang diperoleh bersifat kualitas. Pertanyaan kemana menanyakan tentang apa yang terjadi dimasa lampau, sekarang dan yang akan datang, pengetahuan yang diperoleh adalah pengetahuan yang timbul dari hal yang selalu berulang dapat dijadikan sebagai pedoman, pengetahuan yang terkandung dalam adat istiadat atau kebiasaan yang berlaku dalam masyarakat dan pengetahuan yang timbul dari pedomaan yang dipakai (hukum) sebagai suatu hal yang dijadikan pegangan. Pertanyaan apakah menanyakan tentang hakikat atau nilai mutlak dari suatu hal, jawaban yang diperolah mengetahui hal-hal yang bersifatnya sangat umum, universal dan abstrak.

Dasar pernyataan di atas maka dikatakan bahwa matematika dengan filsafat merupakan dua ilmu yang memiliki hubungan sangat erat dibandingkan dengan ilmu lainnya. Hal ini disebabkan karena filsafat merupakan pangkal atau landasan untuk mempelajari ilmu, sedangkan matematika merupakan ibu atau ratu dari segala ilmu. Ada juga yang beranggapan bahwa Filsafat merupakan salah satu hal yang tidak dapat dipisahkan dengan kehidupan manusia. Hal ini disebabkan karena sejarah filsafat erat kaitannya dengan sejarah mengenai manusia pada masa lalu. Filsafat sebagai pandangan hidup, sangat erat kaitannya dengan nilai-nilai tentang budaya manusia yang dianggap benar yang dijadikan sebagai pandangan hidup. Oleh sebab itu suatu masyarakat atau bangsa dituntut untuk dapat melaksanakan apa-apa saja yang terkandung dalam filsafat tersebut. Dengan kata lain hal-hal yang terkadung dalam filsafat dapat dihubungkan dengan teori kehidupan. Berfilsafat adalah suatu cara berfikir dan bertindak benar dengan menggunakan akal pikiran sebagai instrumen utama untuk dapat mengetahui secara murni berbagai realitas yang ada dan yang mungkin ada di dunia ini dan nilai-nilai dalam hidup dan kehidupan manusia (Muhmidayeli, 2011). Ada empat hal yang menyebabkan manusia berfilsafat yaitu keraguan, ketakjuban, ketidakpuasan, dan hasrat bertanya (Sukardjono, 2000).

Pendidikan merupakan sebuah kebutuhan esensi manusia. Jika manusia tidak memiliki pendidikan yang baik maka ia tidak akan dapat berkreasi, berinovasi dan melangsungkan kehidupannya dengan baik (Husamah, Restian, \& Widodo, 2015; Salim, 2019; Digdoyo, 2019; Winangsit \& Sinaga, 2020). Oleh karena itu, peranan manusia sebagai khalifah memiliki kewajiban untuk menempuh pendidikan sepanjang hayat sebagaimana ada pepatah yang menyatakan "Tuntutlah ilmu dari buwaian hingga liang lahat" atau "Tuntutlah ilmu hingga ke negeri Cina" (Setiawan, 2018; Harahap, 2019; Iswati, 2020). Dua pepatah ini mendukung gambaran bahwa pendidikan itu sangat penting untuk di miliki oleh semua orang. Sebab pendidikan akan membawah masyarakat untuk dapat menghadapi masalah dan pertanyaan masa lalu, masa kini dan masa yang akan datang. Pendidikan akan menjadi bekalan bagi masyarakat dalam menjalankan kehidupannya dengan baik dan dapat menjalankan tujuan penciptaan dari manusia itu sendiri. Hal itu dikarenakan dalam proses pendidikan ada beberapa komponen yang harus menjadi prioritas agar berlangsungnya pendidikan dengan baik. Jika pendidikan berjalan dengan baik maka akan menjadikan Negara itu berkembang maju. Sebab suatu Negara akan mengalami kemajuan pesat jika sumber daya manusia nya memiliki kualitas pendidikan yang baik.

Pemaparan di atas mendeskripsikan bahwa filsafat pendidikan ini sebagai usaha untuk mengenalkan filsafat dan pendidikan serta hal-hal lain yang berhubungan dengan kedua kata tersebut yaitu filsafat dan pendidian. Filsafat pendidikan adalah disiplin ilmu yang mempelajari dan berusaha mengungkap masalah-masalah pendidikan yang bersifat filosofis. Agar pendidikan mempunyai arti jelas, karena pendidikan sangat besar peranannya dalam membina kemajuan suatu bangsa sesuai dengan filsafat yang diyakini. Tujuan dalam artikel adalah untuk mengetahui pengertian dari filsafat matematika, pengertian dari filsafat pendidikan, dan apa hubungan antara matematika dengan filsafat pendidikan. 


\section{B. Metode Penelitian}

Jenis penelitian ini adalah penelitian kepustakaan. Metode penelitian kepustakaan (library research) adalah metode pengumpulan data dengan mencari informasi lewat buku, majalah, koran, dan literatur lainnya yang bertujuan untuk membentuk sebuah landasan teori (Arikunto, 2010). Sedangkan penelitian kepustakaan (library research) mengemukakan riset pustaka membatasi kegiatannya hanya pada bahan-bahan koleksi perpustakaan saja tanpa memerlukan riset lapangan (Zed, 2008).

Penelitian kepustakaan (library research) memiliki empat langkah-langkah yang harus diperhatikan dalam pelaksanaan. Pertama, menyiapkan alat perlengkapan, alat perlengkapan dalam penelitian kepustakaan hanya pensil atau pulpen dan kertas catatan. Kedua, menyusun bibliografi kerja, bibliografi kerja ialah catatan mengenai bahan sumber utama yang akan dipergunakan untuk kepentingan penelitian. Sebagian besar sumber bibliografi berasal dari koleksi perpustakaan yang di pajang atau yang tidak dipajang. Ketiga, mengatur waktu, dalam hal mengatur waktu ini, tergantung personal yang memanfaatkan waktu yang ada, bisa saja merencanakan berapa jam satu hari, satu bulan, terserah bagi personal yang bersangkutan memanfaatkan waktunya. Keempat, membaca dan membuat catatan penelitian, artinya apa yang dibutuh dalam penelitian tersebut dapat dicatat, supaya tidak bingung dalam lautan buku yang begitu banyak jenis dan bentuknya (Khatibah, 2011). Hasil penelitian ini dapat dijadikan sebagai acuan ataupun referensi untuk mencari informasi mengenai perkembangan matematika dalam ilmu filsafat.

\section{Hasil Penelitian dan Pembahasan \\ 1. Pengertian Filsafat Matematika}

Filsafat berasal dari bahasa Inggris dan bahasa Yunani (As-Said, 2011). Pada bahasa Inggris berasal dari kata philosophy, sedangkan dalam bahas Yunani philein atau philos dan sofein atau sophi. Philos artinya cinta, sedangkan sophia artinya kebijaksanaan. Ada pula yang mengatakan bahwa filsafat berasal dari bahasa Arab, yaitu falsafah yang artinya al-hikmah. Dengan demikian filsafat dapat diartikan cinta kebijaksanaan atau al-hikmah. Orang yang mencintai atau mencari kebijaksanaan atau kebenaran disebut dengan filsuf. Kata philosophos diciptakan untuk menekankan suatu pemikiran Yunani seperti Pythagoras (582-496 SM) dan Plato (428-328 SM) yang mengkritik pada sofis (sophists) yang berpendapat bahwa mereka tahu jawaban untuk semua pertanyaan. Dari definisi di atas masih ada beberapa filsuf yang mendefinisikan filsafat. Berikut ini disampaikan beberapa definisi filsafat dari sebagian filsuf (Adib, 2011).

a. Plato (427-348 SM). Filsuf Yunani yang termashur, murid Socrates dan guru Aristoteles ini mendefiniskan filsafat adalah pengetahuan yang berminat mencapai kebenaran yang asli.

b. Aristoteles (382-322 SM). Filsafat adalah ilmu pengetahuan yang meliputi kebenaran mengenai ilmu-ilmu metafisika, logika, retorika, etika, ekonomi, politik dan estetika. Menurut dia ilmu filsafat itu adalah ilmu mencari kebenaran pertama, ilmu tentang segala yang ada yang menunjukkan ada yang mengadakan sebagai penggerak pertama.

c. Al-Farabi (870-950). Filsuf terbesar sebelum Ibnu Sina mendefinisikan filsafat adalah ilmu pengetahuan tentang alam yang maujud dan bagaimana hakekat yang sebenarnya.

d. Rene Descartes (1590-1650), seorang tokoh utama Renaissance, men-definisikan filsafat adalah kumpulan segala pengetahuan dimana Tuhan, alam dan manusia menjadi pokok penyelidikannya.

e. Immanuel Kant (1724-1804), seorang filsuf yang sering disebut raksasa pikir Barat mendefinisikan filsafat adalah ilmu pokok dan pangkal segala pengetahuan yang mencakup di dalamnya empat persoalan, yaitu: 1) Met afisika, menjawab apa yang dapat kita ketahui; 2) Etika, menjawab apa yang boleh kita kerjakan; 3) Agama, menjawab sampai dimana harapan kita; 4) Antropologi, menjawab apa yang dinamakan manusia. 
f. Theodore Brameld, mendefinisikan filsafat merupakan usaha yang gigih dari orang-orang biasa maupun orang-orang cerdik pandai untuk membuat kehidupan sedapat mungkin dapat dipahami dan bermakna

Dari defenisi yang dikemukan pada oleh para ahli diatas maka dapat disimpulkan bahwa filsafat adalah ilmu pengetahuan yang mencari nilai kebenaran dari esensi suatu permasalahan. Matematika berasal dari bahasa Yunani yaitu mathematikos berarti ilmu pasti, dari kata mathema atau mathesis yang berarti ajaran, pengetahuan, atau ilmu pengetahuan (Herman, 2003). Istilah Matematika menurut bahasa Latin (manthanein atau mathema) yang berarti belajar atau hal yang dipelajari, yang kesemuanya berkaitan dengan penalaran.

Filsafat dan matematika sudah tidak diragukan lagi bahwa sejak dulu sampai sekarang kedua bidang pengetahuan ini sangat erat hubungannya. Filsafat matematika adalah cabang dari filsafat yang mengkaji anggapan-anggapan filsafat, dasar-dasar, dan dampak-dampak matematika. Tujuan dari filsafat matematika adalah untuk memberikan rekaman sifat dan metodologi matematika dan untuk memahami kedudukan matematika di dalam kehidupan manusia. Bidang pengetahuan yang disebut filsafat matematika adalah hasil pemikiran filsafat yang sasarannya ialah matematika itu sendiri. Filsafat matematika berperan menyediakan landasan/pondasi pengetahuan matematis yang sistematis dan yang secara absolut dapat melindungi landasan tersebut dari berbagai macam kontradiksi dan paradok dalam kaitannya dengan kebenaran matematis (Sukardjono, 2000). Peran yang seperti ini berkaitan dengan dasardasar landasan matematika yang telah dikembangkan oleh aliran absolutisme yang menjadi pusat dari seluruh filsafat matematika, saat ini. Perincian bidang filsafat matematika yang dapat dikemukakan dan diharapkan lebih sistematis mencakup beberapa bagian sebagai berikut (Slamet, 2008):

a. Epistemologi matematik

Epistemologi matematik adalah teori pengetahuan yang sasaran penelaahannya ialah pengetahuan matematik. Epistomologi sebagai salah satu bagian dari filsafat merupakan pemikiran reflektif terhadap berbagai segi dari pengetahuan seperti kemungkinan, asalmula, sifat alami, batas-batas, asumsi dan landasan, validitas dan reliabilitas sampai kebenaran pengetahuan. Dengan demikian landasan matematik merupakan pokok soal utama dari epistemologi matematik.

b. Ontologi matematik

Ontologi pada akhir-akhir ini dipandang sebagai teori mengenai apa yang ada. Hubungan antara pandangan ontologis (atau metafisis) dengan matematik cukup banyak menimbulkan persoalan-persoalan yang dibahas oleh sebagian filsuf matematik. Dalam ontologi matematik dipersoalkan cakupan dari pernyataan matematik (cakupannya suatu dunia yang nyata atau bukan). Pandangan realisme empirik menjawab bahwa cakupan termaksud merupakan suatu realitas. Eksistensi dari entitas-entitas matematik juga menjadi bahan pemikiran filsafati. Terhadap problim filsafati ini pandangan Platonisme menjawab bahwa titik dan garis yang sesungguhnya terdapat dalam dunia transenden yang kini hanya diingat oleh jiwa manusia di dunia ini, sedang konsepsi Aristotelianisme mengemukakan bahwa entitas-entitas itu sungguh ada dalam dunia empirik tetapi harus disuling dengan abstraksi. Suatu hal lagi yang merupakan problim yang bertalian ialah apakah matematik ditemukan oleh manusia atau diciptakan oleh budinya

c. Aksiologi matematik

Aksiologi matematika terdiri dari etika yang membahas aspek kebenaran, tanggung jawab dan peran matematika dalam kehidupan, dan estetika yang membahas mengenai keindahan matematika dan implikasinya pada kehidupan yang bisa mempengaruhi aspekaspek lain terutama seni dan budaya dalam kehidupan. Aksiologi matematika sangat banyak memberikan kontribusi perubahan bagi kehidupan umat manusia di jagat raya nan fana ini. Segala sesuatu ilmu di dunia ini tidak bisa lepas dari pengaruh matematika. 
Sehingga dapat dikatakan Filsafat matematika adalah cabang ilmu pengetahuan dari filsafat yang mengkaji anggapan-anggapan filsafat, dasar-dasar, dan dampak-dampak matematika serta meencari kebenaran dari fenomena-fenomena dalam pendidikan.

\section{Pengertian Filsafat Pendidikan}

Berbagai ragam pendapat dan statement yang dikemukakan mengenai pengertian dari pendidikan. Diantaranya Dalam Kamus Besar disebutkan "Pendidikan sebagai proses pengubahan sikap dan tata laku seseorang atau kelompok orang dalam usaha mendewasakaan manusia melalui upaya pengajaran dan latihan, proses perbuatan, dan cara mendidik". Selain pengertian tersebut, ada pengertian yang dikemukan oleh ahli, diantaranya :

a. Driyarkara

Pendidikan adalah memanusiakan manusia. Definisi ini menunjukkan bahwa pendidikan merupakan usaha yang sistematis yang bertujuan agar setiap manusia mencapai satu tahapan tertentu di dalam kehidupannya, yaitu tercapainya kebahagiaan lahir batin.

b. Edward Humrey

Education mean increase of skill develofment of knowlodge and undestanding as a result of training, study or experience yang diartikan Pendidikan adalah sebuah penambahan ketrampilan atau pengembangan ilmu pengetahuan dan pemahaman sebagai hasil latihan, study atau pengalaman.

c. Heidjrachman dan Husnah (1997:77) pendidikan adalah suatu kegiatan untuk meningkatkan pengetahuaan umum seseorang termasuk di dalam peningkatan penguasaan teori dan keterampilan, memutuskan dan mencari solusi atas persoalanpersoalan yang menyangkut kegiatan di dalam mencapai tujuannya, baik itu persoalan dalam dunia pendidikan ataupun kehidupan sehari-hari

d. Ki Hajar Dewantara

Pendidikan adalah menuntun segala kekuatan kodrat yang ada pada anak agar mereka sebagai manusia dan anggota masyarakat dan mencapai keselamatan dan kebahagiaan yang setinggi-tingginya.

e. Theodore Brameld

Educatuion as power means comptent and strong enough to enable us, the majority of people, to decide what kind of a world we want and how to achieve that kind world. Pendidikan sebagai kekuatan berarti mempunyai kewenangan yang cukup kuat bagi kita, bagi rakyat banyak untuk menentukan suatu dunia bagaimana yang kita inginkan dan bagaimana yang kita inginkan dan bagaimana mencapai dunia semacam itu. (Anwar, 2015)

Selain dari pendapat para ahli mengenai pengertian pendidikan. Terdapat juga dalam pembukaan UUD 1945 bahwa mencerdaskan kehidupan bangsa merupakan cita-cita dari Negara Indonesia. Amanat tersebut secara hierarkis dituangkan ke dalam berbagai undang-undang dan peraturan yang mengatur tentang pendidikan. Undang-Undang Nomor 20 Tahun 2003 tentang Sistem Pendidikan Nasional, disebutkan bahwa pendidikan adalah usaha sadar dan terencana untuk mewujudkan suasana belajar dan proses pembelajaran agar peserta didik secara aktif mengembangkan potensi dirinya untuk memiliki kekuatan spiritual keagamaan, pengendalian diri, kepribadian, kecerdasan, akhlak mulia dan ketrampilan yang diperlukan dirinya, masyarakat, bangsa dan Negara.

Dari pemaparan mengenai filsafat dan pendidikan dapat maka dapat kita katakana bahwa Filsafat pendidikan adalah ilmu pengetahuan yang pada hakikatnya merupakan jawaban dari pertanyaan-pertanyaan, fenomena-fenomena dalam bidang pendidikan yang dilihat dari segi filsafatnya.

\section{Hubungan antara Matematika dengan Filsafat Pendidikan}

Matematika dan filsafat merupakan dua istilah yang tidak dapat dipisahkan. Keduanya memiliki hubungan yang erat. Jika ada yang menyatakan bahwa filsafat merupakan ayah ibu dari 
matematika adalah keliru. Matematika tidak pernah lahir dari filsafat, melainkan keduanya berkembang bersama-sama dan saling berkontribusi dengan berbagai persoalan-persoalan sebagai bentuk input dan outpot. Dalam lintasan sejarah kedua saudari kembar filsafat dan matematika itu selanjutnya tumbuh bersama-sama dibawah asuhan filsuf yang juga ahli matematika pythagoras (572-497 S.M.). Dan seorang ahli astronomi terkenal yang berbicara tentang matematika dalam kaitannya dengan filsafat ialah Galileo Galilei (1564-1642). Ucapannya yang banyak dikutip yaitu: "philosophy is writen in this grand book, the universe, which stands continually open to our gaze. But the book cannot be understood unlees one first learns to comprehend the language and read the letters in which it is composed. It is written in the language of mathematics." (Filsafat telah ditulis dalam buku besar ini, yakni jagad raya yang terus menerus terbang terbuka bagi pengamatan kita. Tetapi buku itu tidak dapat dimengerti jika seseorang tidak lebih dahulu belajar memahami bahasa dan membaca huruf-huruf yang dipakai untuk menyusun.Buku itu ditulis dalam bahasa matematik).

Filsafat dan matematika memiliki hubungan yang erat, antara lain:

a. Filsafat dan geometri (suatu cabang matematika) lahir pada masa yang sama, di tempat yang sama, dan dari ayah yang tunggal, yakni sekitar 640-546 sebelum Masehi, di Miletus (terletak di pantai barat negara Turki sekarang) dan dari pikiran seorang bernama Thales.

b. Menjalin-menjalin antara metafisika (khususnya kosmologi yang merupakan ajaranajaran tentang jagad raya) dengan matematika (khususnya geometri dan teori bilangan yang menelaah bentuk geometris dan sifat alami bilangan) sebagai mana dipadukan oleh filsuf-filsuf kuno kemudian diperkuat oleh ilmuan-ilmuan modern. Misalnya saja sebagai pelengkap dari pendapat Plato bahwa Tuhan senantiasa bekerja dengan metode geometri, ahli matematika C.G.J.Jacobi (1804-1851) menyatakan bahwa God ever arithmetizes (Tuhan senantiasa melakukan aritmatik). Pendapat Plato di atas juga terpantul dalam seni.

c. Suatu pristiwa terjadi dalam 1794 pada diri pelukis Inggris yang terkenal bernama William Blake (1757-1827). Ia melihat suatu pandangan khayal (vision) yang menunjukan Tuhan sedang menciptakan dunia ini dari ruang yang masih hampa dengan mempergunakan sebuah jangka sebagaimana layaknya seorang ahli geometri. Gambar bayangan itu berlangsung selama seminggu diatas tangga rumahnya sehingga akhirnya Blake memutuskan untuk melukiskan pada kanvas. Lukisan tersebut yang tampaknya mencerminkan ucapan Plato itu kini terkenal dan berjudul The anciet of Days (sepuluh Zaman).

d. Sejalan artinya dengan kedua pernyataan itu seorang ahli astronomi dan fisika James H. Jeans (1877-1946) menyatakan bahwa "the Architect of the universe now begins to appear as a pure mathematician" (Arsitek Agung dari jagat raya kini mulai tampak sebagai seorang ahli matematika murni). Sedang nama samaran Le Corbusier yang nama aslinya ialah Charles Edouard Jeanneret (887-1965) mengemukakan : "Mathematics is the majestic structure conceved by man to grant him comprehension of the universe" (Matematika adalah struktur besar yang dibangun oleh manusia untuk memberikan pemahaman mengenai jagad raya).

e. Matematika tidak pernah lahir dari filsafat, melainkan keduanya berkembang bersamasama dengan saling memberikan persoalan-persoalan sebagai bahan masuk dan umpan balik.

f. Adanya hubungan timbal balik dan saling pengaruh antara filsafat dan matematika dipacu pula oleh filsuf Zeno dari Elea. Zeno memperbincangkan paradoks-paradoks yang bertalian dengan pengertian-pengertian gerak, waktu, dan ruang yang kemudian selama berabad-abad membingungkan para filsuf dan ahli matematik.

g. Wahyudi (2011), mengemukakan hubungan antara matematika dengan filsafat adalah upaya-upaya intelektual paling awal untuk memahami dunia di sekitar kita, dan keduanya lahir di Yunani Kuno serta mengalami transformasi-transformasi penting disana. Matematika adalah suatu studi kasus penting bagi filsuf. Agenda filsafat kontemporer 
memiliki formulasi-formulasi yang sangat jelas berfokus pada matematika, yang meliputi Epistomologi dan Ontologi.

Hal diatas diperkuat dengan tujuan dari belajar Matematika itu sendiri berupa 1) Math Teaches you to admit when you are wrong "Mengajarkan Anda untuk mengakui ketika anda salah", 2) To choose exact and correct words "Untuk memilih kata yang tepat dan benar", 3) To think several steps ahead (move on)" Berpikir beberapa langkah ke depan (move on), 4) Not like everyone else but in your own way" Tidak mudah percaya dengan orang lain", 5) Never give up " Tidak gampang menyerah".

Pemaparan pada paragraf sebelumnya menunjukkan adanya persamaan dan perbedaan dari matematika dengan filsafat pendidikan yang dapat dipahami dari Tabel 1 berikut.

Tabel 1. Perbedaan dan Persamaan Dari Matematika Dan Filsafat Pendidikan

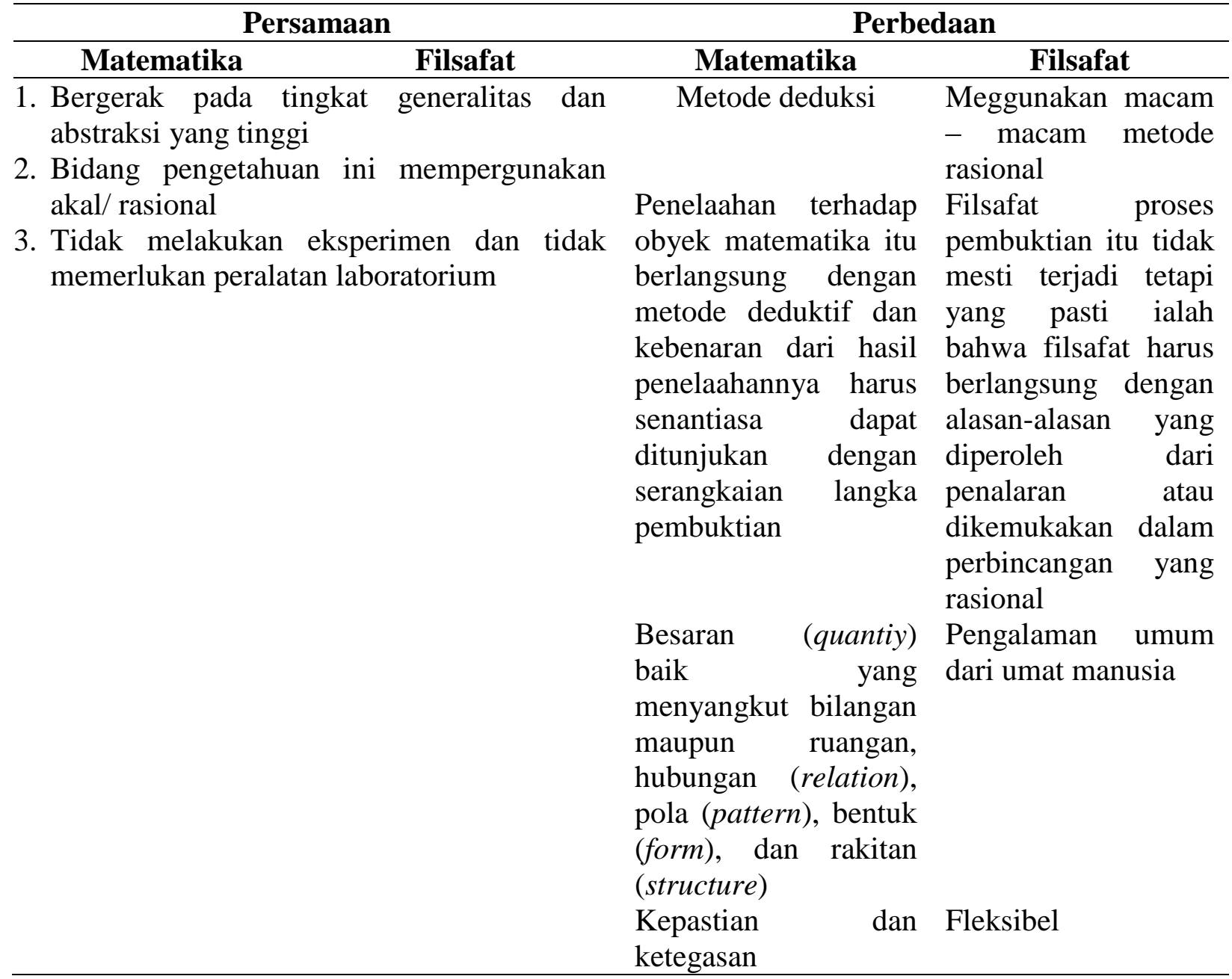

Dari persamaan yang terlah dituliskan pad tabel 1 maka dapat ditarik kesimpulan mengenai hubungan antara filsafat dan matematika adalah bergerak pada tingkat generalitas dan abstraksi yang tinggi, bidang pengetahuan ini mempergunakan akal/ rasional dan tidak melakukan eksperimen dan tidak memerlukan peralatan laboratorium dalam membuktikan kebenaran.

\section{Simpulan}

Berdasarkan pemaparan, disimpulkan: (1) Filsafat matematika adalah cabang dari filsafat yang mengkaji anggapan-anggapan filsafat, dasar-dasar, dan dampak-dampak matematika. Tujuan dari filsafat matematika adalah untuk memberikan rekaman sifat dan metodologi matematika dan untuk memahami kedudukan matematika di dalam kehidupan manusia. (2)Filsafat pendidikan adalah ilmu yang pada hakikatnya merupakan jawaban dari pertanyaan- 
pertanyaan dalam bidang pendidikan. (3) Hubungan matematika dengan filsafat pendidikan merupakan hubungan yang saling berkesinambungan satu sama lain. Dimana matematika dan filsafat pendidikan sama-sama membahas mengenai pengetahuan yang didasarkan pada akal dan rasional. Serta sama-sama mencari kebenaran dalam bidang pendididkan dan membahas fenomena-fenomena dalam pendidikan.

\section{DAFTAR PUSTAKA}

Adib, Mohammad. (2011). Filsafat Ilmu Ontologi, Epistimologi, Aksiologi dan Ilmu Pengetahuan. Yogyakarta: Pustaka Pelajar.

Anwar, M. (2015). Filsafat pendidikan. Jakarta: Kencana.

As-Said, Muhammad. (2011). Filsafat Pendidikan Islam. Yogyakarta: Mitra Pustaka.

Digdoyo, E. (2019). Rumah Puspo Budaya Nusantara Sebagai Pusat Pengembangan Pendidikan Karakter Melalui Tari Nusantara. Integralistik, 30(1).

Ginting, P., \& Situmorang, S. H. (2008). Filsafat Ilmu dan Metode Riset. Terbitan Pertaman. Medan USU Press.

Harahap, M. (2019). Hakikat Belajar dalam Istilah Ta'allama, Darasa, Thalaba, Perspektif Pendidikan Agama Islam. Al-Hikmah: Jurnal Agama dan Ilmu Pengetahuan, 16(2), 130144.

Haryanto. (2012). Pengertian pendidikan menurut para akhli http://belajarpsikologi. com/pengertian-pendidikan-menurut-ahli/

Heidjrachman, dkk. (2011). Manajemen Personalia. Yogyakarta: BPFE.

Heris, Hermawan. (2012). Filsafat Pendidikan Islam. Direktorat Jenderal Pendidikan Islam: Kementerian Agama

Herman Hudoyo. (2003) Pengembangan Kurikulum dan Pembelajaran Matematika. Malang: Universitas Negeri Malang

Husamah, H., Restian, A., \& Widodo, R. (2015). Pengantar Pendidikan. Research Report.

Iswati, I. (2020). LONG LIFE EDUCTION DALAM PERSPEKTIF HADITS (Suatu Tinjauan Pendidikan Sejak Pranatal dan Analisis Terhadap Kualitas Hadits Pendidikan Sepanjang Hayat). At-Tajdid: Jurnal Pendidikan dan Pemikiran Islam, 3(2), 126-147.

Lasarus, M. (2020). Efektivitas Pendekatan Kontekstual Dalam Pembelajaran Matematika Siswa Kelas VIII SMP Negeri 4 Sesean Satap. Zigma: Jurnal Pendidikan Matematika, 1(1), 9-11.

Peraturan Perundang-undangan. (2003). Undang-Undang No. 20 tahun 2003 Tentang Sistem Pendidikan Nasional. Jakarta

.(2005). Undang-undang No. 14 Tahun 2005 Tentang Guru dan Dosen. Jakarta

Salim, A. (2019). Kurikulum Dalam Perspektif Filsafat Pendidikan Islam. EduTech: Jurnal Ilmu Pendidikan Dan Ilmu Sosial, 5(2).

Setiawan, D. (2018). ILMU PENGETAHUAN DALAM AL-QUR'AN (Science in the Qur'an). Jurnal Ilmiah Al-Hadi, 3(2), 641-656.

Slamet, Ibrahim. (2008). Power point FILSAFAT ILMU PENGETAHUAN . Sekolah Farmasi ITB

Syadali, Ahmad \& Mudzakir. (1997). Filsafat Umum. Bandung: Pustaka Setia

Susanto, A. (2021). Filsafat ilmu: Suatu kajian dalam dimensi ontologis, epistemologis, dan aksiologis. Bumi Aksara.

Winangsit, E., \& Sinaga, F. S. H. S. (2020). Esensi Pendidikan Musik Berbasis Industri Budaya di Tengah Pandemi Covid-19. In Prosiding Seminar Nasional Pascasarjana (PROSNAMPAS) (Vol. 3, No. 1, pp. 989-995). 